Dr. Sabina Jelenc

Krašovec

Filozofska fakulteta

Univerze v Ljubljani

\section{STAREJŠI DELAVCI NA TRGU DELOVNE SILE}

\title{
POVZETEK
}

Napovedi kažejo, da bodo demografske spremembe v prihodnosti močno vplivale na spreminjanje strukture delovne sile. Zaradi skorajšnjega množičnega upokojevanja generacije »baby-booma «lahko pričakujemo padec deleža delovno aktivnega prebivalstva in posledično spreminjanje možnosti za socialno in zdravstveno varstvo prebivalstva. Evropska politika pritiska na države članice z zahtevami po zviševanju upokojitvene starosti, ob tem pa se postavljajo vprašanja, kakšne spremembe prinaša zaposlovanje starejših delavcev, kakšne so potrebe po zaposlovanju starejših delavcev in kako, ob kakšnih ukrepih lahko nove vzorce zaposlovanja tudi vpeljemo. V prispevku tudi izpostavljamo vprašanje izobraževanja kot pomembnega dejavnika zaposlovanja starejših delavcev.

Ključne besede: dejavno staranje, premostitvene zaposlitve, izobraževanje (starejših) delavcev

$\mathrm{S}$ staranjem prebivalstva se stara tudi delovna sila in, kot ugotavljamo, bo proces verjetno $\mathrm{v}$ prihodnosti še intenzivnejši. Po napovedih naj bi se $\mathrm{v}$ prihodnjih letih struktura delovne sile intenzivno spreminjala; število mladih (do 30 let) naj bi padalo, število starejših (od 50 do 64 let) pa naraščalo (Eurostat, Projected old-age...). Predvidevamo, da bodo delodajalci $\mathrm{v}$ takšnih razmerah prisiljeni poiskati nove možnosti, ker bo mladih delavcev preprosto premalo, da bi nadomestili manko, nastal s povečevanjem upokojevanja. V zadnjih letih je v Evropi v povprečju ekonomsko dejavnih več kot 40 odstotkov starejših delavcev ${ }^{1}$ (starih od 55 do 64 let), delež se bo po napovedih stalno povečeval.

V življenjskem ciklu tradicionalno velja, da so mladi in stari dejavni predvsem $\mathrm{v} \gg$ nepoklicnih« vlogah, medtem ko je srednja generacija dejavna predvsem $\mathrm{v}$ poklicnih vlogah oziroma vlogah, povezanih z zaposlitvijo. To pomeni, da je velik del populacije (to posebno velja za starejše) izključen iz procesa produkcije, kar je najbolj pomembna institucija, ki definira odraslost. Velika kohorta odraslih, ki so zdaj v obdobju pozne odraslosti ali zgodnje starosti, bo morda poskušala vplivati na spreminjanje teh stereotipov. Boljše zdravje prispeva, da se ne počutijo »stari«, povprečno višja stopnja izobrazbe pa vpliva na dejstvo, da se mnogi težko identificirajo z obrobnimi vlogami, ki so pripisane starejšim. Ker gre za veliko in raznoliko skupino ljudi, bodo gotovo imeli pomemben vpliv tudi na družbena stališča, saj so dejavno vključeni tako $v$ potrošnjo kot $\mathrm{v}$ politiko, delo in druga področja življenja.

Pri analizi položaja starejših delavcev bomo v prispevku izhajali iz ključnih predpostavk.

- Večina razvitih držav je zaradi demografskih sprememb v obdobju, ko lahko pričakuje množično upokojevanje številne generacije »baby-booma«, kar bo povzročilo velik padec deleža delovno aktivnega prebivalstva. Različne raziskave kažejo, da namerava 80 odstotkov te generacije delati dlje od tradicionalno pričakovane starosti 
upokojevanja (Haris Interactive, 2005).

- Ob spreminjanju razmerij med viri financiranja upokojencev, ki so večinoma sestavljeni tridelno - iz socialnih virov, zasebnih virov in virov podjetij - je zaradi zmanjšanja števila delovno aktivnega prebivalstva ogrožena socialna blaginja, kar pomeni slabše možnosti za socialno in zdravstveno varstvo prebivalstva.

- Na ravni države bo treba čim prej sprejeti dejavno politiko zaposlovanja, ki naj bi poleg gospodarskih dejavnikov - upoštevala tudi značilnosti in potrebe starejših delavcev.

Do nedavnega so se politiki v Evropski uniji osredotočali predvsem na tri stebre upokojitvenih dohodkov (javnega, zasebnega in poklicnega), zanemarjen pa je bil vir, ki bi ga starejši delavci pridobili z zaposlitvijo (Walker, 2001). Ta bi v prihodnosti lahko predstavljala četrti steber dohodkov, saj postaja zaposlovanje v starosti vse pomembnejše, koncept dejavnega staranja pa vse pomembnejša politična prioriteta. Po nekaterih predvidevanjih bi ob zmanjševanju javnih sredstev za upokojevanje, zmanjševanju različnih vrst pokojnin in verjetnem zmanjševanju prihrankov občasno ali stalno delo starejših ljudi lahko postalo nujnost. Starejši delavci, ki so imeli uspešne kariere in sorazmerno dobre dohodke, bodo dobro zaslužili tudi v starosti, ravno nasprotno pa velja za nižje izobražene starejše, ki bodo tudi v starosti imeli izredno majhne dohodke.
Zato Chen in Scott (2003: 64) ugotavljata, da bodo bolj ogroženi nižje izobraženi starejši, ki so opravljali slabše plačana dela, saj so (in bodo) bolj odvisni od javnih sredstev za socialno varnost, ki pa se stalno zmanjšujejo. Menita tudi, da sicer obstaja velika potreba po premostitvenih zaposlitvah oziroma možnostih za postopno upokojevanje starejših delavcev, vendar pa hkrati obstaja kar veliko ovir za njihovo resnično uvajanje - te so lahko legalne, povezane s cilji načrtovanja upokojevanja, ali pa gre za druge ovire, kot na primer oviranje vzpostavljanja programa za postopno upokojevanje s strani delovne orgaUpokojitev je razmeroma nova institucija, nastala na začetku 20. stoletja. nizacije, zagotavljanje zdravstvenega varstva za zaposlene (tudi za starejše, ki so ponovno/ delno vključeni $v$ zaposlitev) in druge (Chen in Scott, 2003: 65-66).

\section{STAREJŠI DELAVCI NA TRGU DELOVNE SILE}

Položaj starejših delavcev na trgu delovne sile se zaradi omenjenih dejavnikov v zadnjih dvajsetih letih pomembno spreminja, predvsem dramatične so spremembe $v$ upokojevanju starejših delavcev. Upokojitev je sicer razmeroma nova institucija, in čeprav so nekateri formalni programi upokojevanja obstajali že v 19. stoletju, je bila večina delavcev
Od leta 1950 so večja prosperiteta in socialno bolj ugodni programi upokojevanja dovoljevali mnogim delavcem vse bolj zgodnje upokojevanje, podprti so bili s socialnim zavarovanjem, natančnimi načrti višine pokojnin in zasebnimi prihranki. Povprečna starost je ob upokojitvi v 20. stoletju (pri moških) stalno padala. ${ }^{2} \mathrm{~V}$ 80. letih sta se zaradi tehnoloških sprememb (boljša produktivnost), izboljšanja zdravja in podaljševanja življenjske dobe ter spreminjanja narave dela (več prostega časa) posledično spreminjala tudi delovna kariera in čas upokojevanja. Vloga »pričakovanih let« upokojevanja je postala zabrisana, obseg let, primernih za upokojitev, se je bistveno razpotegnil, prehod je postal dolg in nejasen. Proces upokojitve je postopno postajal »detradicionaliziran«, »deinstitucionaliziran « in »starostno nepomemben « proces (Han in Moen, 1999: 192). 
v starosti odvisna od pomoči družine ali lastnih prihrankov. V 20. stoletju so se v okviru različnih sistemov (države blaginje in socialistične države) sistemi upokojevanja različno razvijali, vendar pa je zgodnejše upokojevanje vplivalo na nastanek starostno segregiranega delovnega okolja.

Zelo verjetno je, da se bodo zaradi spreminjanja sistema socialne varnosti viri financiranja ob upokojevanju v Evropi in ZDA v prihodnosti še bolj spreminjali (Cahill in dr., 2006a: 514). Podatki kažejo, da je višina zasebnih prihrankov v ZDA najnižja od zadnje velike depresije v 30. letih prejšnjega stoletja (prav tam), zaradi krize pa se s podobnim gibanjem srečuje tudi večina evropskih držav. S potencialnim zmanjšanjem ključnih virov dohodka pri upokojevanju ter ob hkratnem zmanjševanju ugodnosti pri zdravstvenem varstvu bodo mnogi starejši morali izbrati bodisi daljšo delovno dobo bodisi nižji življenjski standard in upokojitev.

Zaradi staranja prebivalstva, ki že zelo intenzivno poteka, se bomo tudi v Sloveniji soočali z večjim deležem starejših delavcev med celotno delovno silo. Staranje družbe je pri nas še vedno preveč prezrto razvojno dejstvo, ki kaže, da bo ob enakem vzorcu upokojevanja in delovne aktivnosti (ob nespremenjenih parametrih) povzročilo veliko povečanje potreb javnih izdatkov za stare (za pokojnine, za zdravstvo in za druge izdatke) (Kajzer, 2007: 27). Eurostatove napovedi kažejo, da bo delež starejših od 65 let v Sloveniji leta 201024 odstotkov predvidenega števila oseb, starih od 15 in 64 let, leta 2025 bo ta delež 36 odstot- kov predvidenega števila oseb, starih od 15 do 64 let, do leta 2060 pa že 62 odstotkov števila oseb, starih od 15 do 64 let. Ugotovimo lahko, da se bo po predvidevanjih delež prebivalstva, starejšega od 65 let, do leta 2050 podvojil. Ta napoved potrjuje predvidevanja, da bodo demografske spremembe $v$ povezavi $\mathrm{s}$ staranjem prebivalstva bolj izrazite $\mathrm{v} \mathrm{dr}$ žavah srednje in vzhodne Evrope (Eurostat, Projected old-age...).

Večji delež starejšega prebivalstva, ki je posledica spremenjene starostne strukture prebivalstva, lahko zaradi zmanjšanja števila delovno aktivnega prebivalstva povzroči padanje gospodarske rasti. Nekatere ocene kažejo, da se bo potencialna gospodarska rast $\mathrm{v}$ Sloveniji in v EU na daljši rok zniževala in naj bi v Sloveniji v obdobju od 2041 do 2050 znašala manj kot tretjino sedanje potencialne rasti (Carone in dr., 2006 v Kajzer 2007). Že danes se tudi v Sloveniji spopadamo z veliko strukturno brezposelnostjo, hkrati pa obstajajo »strokovno podhranjena « področja, ki zahtevajo najemanje tuje delovne sile. Ves čas je tudi prisotno upadanje števila delovno aktivnega prebivalstva, hkrati pa zviševanje števila brezposelnih oseb (SURS, Aktivno prebivalstvo...). Slovenija se je s podpisom lizbonske strategije zavezala, da bo do leta 2010 dosegla 50-odstotno zaposlenost starejših delavcev (starih od 55 do 64 let), vendar pri uresničevanju obljub zaostaja. V Sloveniji se v primerjavi z drugimi evropskimi državami srečujemo z eno najnižjih stopenj zaposlenosti starejših delavcev (Hribar Milič, 2008: 21). Stopnja zaposlenosti starejših se je od leta 2000, ko je znašala 22,3 rejših delavcev (starih od 65 do 69 let) (Program stabilnosti 2006: 38). Pri doseganju teh ciljev izstopajo predvsem skandinavske države, ki že dlje časa spodbujajo zaposlovanje starejših delavcev; tako imajo več kot 50 odstotkov zaposlenih v starostni skupini od 55 do 64 let, na primer Švedska, Danska, Estonija, Portugalska, Finska in Velika Britanija. Te države so v zadnjih desetih letih oblikovale politiko dejavnega staranja, s katero so zelo uspešno dvignile stopnjo delovne uspešnosti starejših delavcev (Kajzer, 2007). 
odstotka, do leta 2007 dvignila na 33,5 odstotka, kar pa je precej manj od povprečja EU27 in EU15 v letu 2007 (stopnja zaposlenosti znaša 44,7 odstotka oziroma 46,6 odstotka) (Zupančič, 2008: 13; Hribar Milič, 2008: 21; Statistični portret... 2008: 10). Zaposlenost starejših delavcev se je v Sloveniji v zadnjih dveh letih dvignila le za 2,7 odstotka, kar je izredno malo.

V skladu z lizbonsko strategijo naj bi evropske države do leta 2010 premaknile starostno mejo upokojevanja na 65 let, kar ta čas dosegajo predvsem stare članice EU, države srednje in jugovzhodne Evrope pa ne. Podatki za Slovenijo kažejo, da je bila v letu 2007 starost ob izstopu s trga delovne sile 59,8 leta (Eurostat, Average exit age...), kar pomeni, da bo zastavljene cilje zelo težko dosegla.

Tudi podatki o gmotnem položaju prebivalcev Slovenije izkazujejo vpliv demografskih sprememb, ki zaradi vplivov na socialno, zdravstveno in zaposlitveno politiko vplivajo na blaginjo prebivalstva; tako se kažejo velike razlike med posameznimi skupinami prebivalstva, med katerimi so starejši močno ogroženi. Po podatkih Raziskovanja o dohodkih in življenjskih pogojih (SILC) za leto 2007 je bila stopnja tveganja revščine v Sloveniji 11,5-odstotna, v najslabšem položaju so bila gospodinjstva brez delovno aktivnih članov. Tako so bila v najslabšem položaju enočlanska gospodinjstva (pod pragom revščine je živelo 39,4 odstotka oseb iz takih gospodinjstev), med katerimi so še posebno izstopale starejše ženske (47,1-odstotna stopnja tveganja revščine) (SURS, Kazalniki dohodka...2007). Stopnja tveganja revščine starejših je nadpovprečna, saj izkazujejo starejše osebe (65+) 20-odstotno stopnjo tveganja revščine.

Evropska komisija ugotavlja, da države članice ne dajejo dovolj prednosti in sredstev za večji dostop odraslih do učenja, to velja še zlasti za starejše in nizko kvalificirane delavce. Večina držav $\mathrm{z}$ najvišjo stopnjo udeležbe $\mathrm{v}$ izobraževanju močno poudarja strategije za učenje odraslih kot del skladne in celotne strategije za vseživljenjsko učenje (http://ec.europa. eu/education/policies/2010/doc/progressreport06_sl.pdf). Zadnji podatki Ankete o izobraževanju odraslih, ${ }^{3}$ v kateri so ugotavljali stopnjo vključevanja $v$ formalno in neformalno izobraževanje, kažejo, da je Slovenija pri vključevanju odraslih (25-64 let) v izobraževanje sicer nekoliko nad povprečjem EU, vendar pa so med odraslimi prebivalci glede udeležbe v izobraževanju pričakovane razlike. Udeležba $\mathrm{v}$ izobraževanju odraslih pada s starostjo in stopnjo izobrazbe; v zadnjih 12 mesecih se je izobraževalo le 27 odstotkov starejših (starih od 50 do 65 let), ki sodijo tudi v kategorijo starejših delavcev. Če imajo

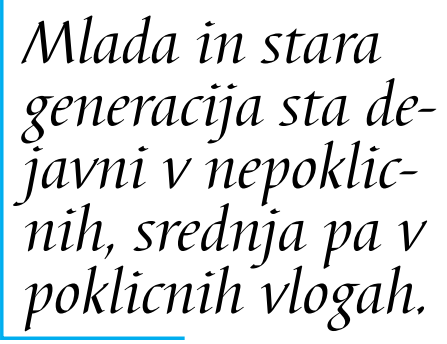
hkrati manj kot srednješolsko izobrazbo, je med njimi delež izobraževalno dejavnih še bistveno manjši (SURS, Anketa o...).

\section{POLITIKA DEJAVNEGA STARANJA IN IZOBRAŽEVANJE}

Politika dejavnega staranja je ta čas ena osrednjih tem razprav v evropski politični agendi. V političnih dokumentih je politika dejavnega staranja razumljena predvsem kot nujnost dvigovanja stopnje delovne aktivnosti starejšega prebivalstva; kljub temu se postavlja vprašanje, v kolikšni meri bo - s pojavom ekonomske, socialne in politične krize - teza o zadrževanju starejših na trgu dela sploh aktualna in uresničljiva. V slikovnem prikazu lahko opazimo velik razkorak med skandinavsko in atlantsko skupino držav blaginje na eni strani ter kontinentalno, centralno in južnoevropsko ter baltsko skupino držav blaginje na drugi strani. Za ilustracijo razlik v doseganju lizbonskih ciljev med članicami EU prikazujemo povezavo udeležbe odraslih v vseživljenjskem učenju $\mathrm{u}^{4}$ deležem delovne aktivnosti starejših oseb (Slika 6). 
Slika 6: Povezanost deležev odraslih (25-64 let), udeleženih v izobraževanju in usposabljanju, s stopnjo delovne aktivnosti starejših oseb (55-64 let) - v letu 2006.
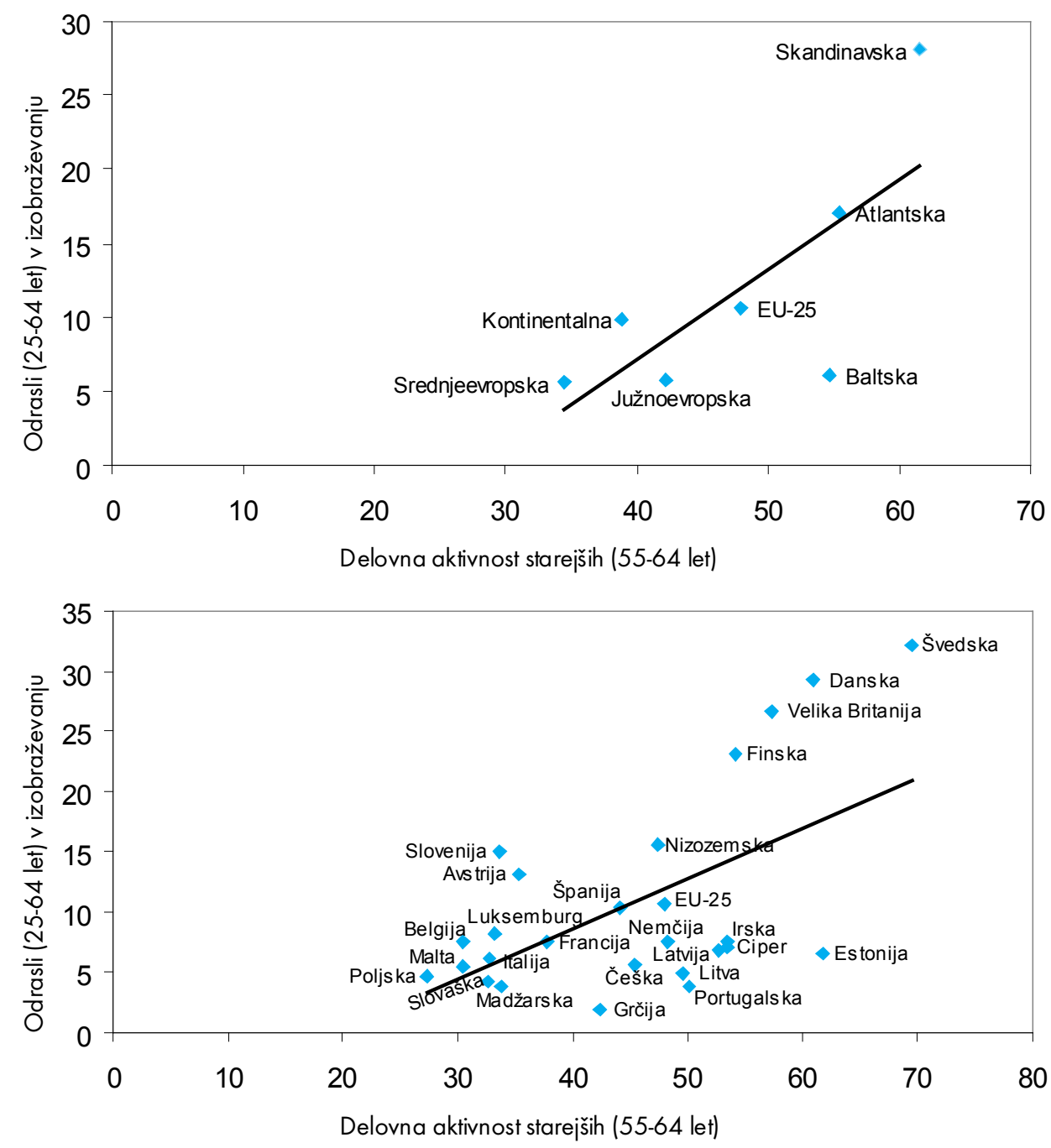

Vir: Sporočilo Komisije Svetu, Evropskemu parlamentu, Evropskemu ekonomsko-socialnemu odboru in Odboru regii, Bruseli, 12. 11. 2007. Dostopno na: http://eur.lex.europa.eu/LexUriServ/site/sl/com/2007/com2007_0703s101.pdf Statistični portret Slovenije v Evropski uniii 2007, Ljubljana: Urad RS za statistiko, 2007.

Dejavno staranje sicer zajema različne dejavnosti, ki spodbujajo neodvisnost in dejavnost starejše generacije, in pomeni »neprekinjeno udejstvovanje na socialnem, ekonomskem, kulturnem in civilnem področju « (Cvahte, 2008: 16). Večina strokovnjakov, ki se ukvarjajo z vprašanji dejavnega staranja, se zaveda, da bodo imeli spremenjeni vzorci upokojeva- nja poleg vpliva na posameznike in državne ukrepe pomemben vpliv tudi na spreminjanje ukrepanja delodajalcev v smeri podpiranja politike dejavnega staranja. Da bo to potrebno, kažejo tudi podatki Združenja delodajalcev Slovenije, ki je v letih 2007 in 2008 še s petimi delodajalskimi združenji iz Avstrije, Hrvaške, Češke, Madžarske in Slovaške med svojimi 
A pravi odnos delodajalcev do zaposlovanja starejših delavcev se pokaže z njihovo pripravljenostjo, da bi na novo zaposlili tako osebo. V Sloveniji je bilo med anketiranimi podjetji le sedem odstotkov takih, ki bi zaposlili starejšo osebo, oziroma povedano drugače: skoraj 80 odstotkov podjetij je v zadnjih treh letih zaposlovalo izključno mlade ljudi (povprečje drugih v projekt vključenih držav je bilo 60 odstotkov). Slovenski delodajalci kot ovire za novo zaposlovanje starejših delavcev navajajo visoko delovnopravno zaščito starejših delavcev in mnoge privilegije, ki jih imajo starejši delavci v primerjavi z mlajšimi (višja plača, strožji pogoji dela, odpravnina, bonusi ipd.). Za izboljševanje situacije delodajalci predlagajo uveljavljanje bolj prožnih prehodov med upokojevanjem in zaposlitvijo, predvsem pa uvajanje ustreznih (finančnih) ukrepov države; menijo tudi, da bi se morali spreminjati tudi starejši sami in poskrbeti za svojo boljšo prilagodljivost, znanje, usposobljenost in mobilnost. Menijo, da privilegiranost starejših delavcev posledično povzroča njihovo marginaliziranost, zato bi bilo treba izenačiti obravnavo starejših in mlajših delavcev. Te ugotovitve in predloge bo treba v prihodnje obravnavati s kritičnim premislekom.

člani izvedlo raziskavo ${ }^{5}$ o zavedanju pomena dejavnega staranja in vlogi delodajalcev pri spodbujanju tega procesa, s ciljem, da bi povečali stopnjo zaposlenosti starejših delavcev. ${ }^{6}$ $\mathrm{V}$ raziskavi je sodelovalo več kot 1300 podjetij iz šestih držav in več kot 630.000 zaposlenih; iz Slovenije 241 podjetij s 66.600 zaposlenimi (Pajnkihar, 2008). Podatki so pokazali, da ima v Sloveniji največ podjetij med svojimi zaposlenimi manj kot pet odstotkov starejših delavcev; med svojimi zaposlenimi ima le 12 odstotkov podjetij več kot 20 odstotkov starejših delavcev (nad 55 let), 42 odstotkov podjetij ima med zaposlenimi od 5 do 20 odstotkov starejših delavcev, 46 odstotkov delodajalcev pa manj kot pet odstotkov starejših od 55 let (Pajnkihar, 2008: 30). Raziskava je nadalje pokazala, da se približno 40 odstotkov podjetij že zaveda, da bodo starejši delavci v prihodnosti bolj pomembni na trgu delovne sile. Več kot polovica anketiranih slovenskih podjetij (55 odstotkov), ki zaposlujejo določen delež starejših delavcev, že zdaj uvaja ukrepe prilagajanja, in sicer uvajajo ustrezno izobraževanje ter prilagajajo delovni proces in delovno mesto potrebam starejših delavcev ter si prizadevajo za spreminjanje podjetniške kulture. Delodajalci tudi navajajo, da svoje starejše zaposlene cenijo zaradi njihovih značilnosti, med katerimi lahko izpostavimo pripadnost podjetju, strokovno znanje, voditeljske in mentorske sposobnosti, odgovornost, zanesljivost ter njihove delovne izkušnje. Med slabostmi pa navajajo težave $\mathrm{z}$ uporabo novih tehnologij, zmožnost učenja novega, znanje jezikov, mobilnost in še nekatere druge (Pajnkihar, 2008: 32).

\section{STEREOTIPI IN ZAPOSLOVANJE STAREJŠIH DELAVCEV}

Pri zaposlovanju je stereotipiziranje lastnosti starejših delavcev, ki največkrat pomeni njihovo diskriminacijo, močno prisotno in je hkrati tudi izredno pomembni razlog za njihovo zgodnje ali predčasno upokojevanje. Diskriminacijo na delovnem mestu spremlja »ageizem ${ }^{7}$, ki je v mnogih državah del ustaljene prakse zaposlovanja in $v$ širšem smislu tudi del družbenega strukturiranja. Gre za sistematično stereotipiziranje in diskriminacijo starejših ljudi zgolj zato, ker so stari. V tem smislu je »ageizem « podoben rasizmu in seksizmu, v kombinaciji pa ti pomenijo večplastno segregacijo. Ageizem je prisoten v delovanju medijev, zdravstvenega varstva, izobraževanja, oglaševanja in seveda zaposlovanja, saj delovno mesto kot »mikrokozmos« odraža družbene stereotipe. Pri zaposlovanju gre največkrat za institucionalni ageizem, v katerem pa se odraža osebni ageizem, ki pogosto deluje na nezavedni ravni (Dennis in Thomas, 2007: 84). Starostne diskriminacije se največkrat ne doživlja kot kršitev temeljnih človekovih pravic, kot to velja za rasno in spolno diskriminacijo, temveč predvsem kot ekonomski problem. 
Raziskave, ki so preučevale učinkovitost starejših delavcev, so pokazale, da so se starejši delavci izkazali bolje kot mlajši delavci (Munnell, Sass in Soto v: Dennis in Thomas, 2007: 86). Kljub temu pa raziskave menedžerskih odločitev kažejo na stereotipno gledanje na starejše delavce; če sta se na primer za isto

Starost se ponavadi diskriminira iz ekonomskih razlogov. delovno mesto prijavila enako usposobljena starejši (57 let) in mlajši (32 let) delavec, je starejši delavec dobival manj ugodne odgovore. Neugoden položaj se je pojavil takoj na začetku, še preden je starejši delavec sploh lahko dokazal svojo usposobljenost. Intervju z njim je bil krajši, dobil je manj pooblastil in manj ponudb za delo (Dennis in Thomas, 2007: 87). To se dogaja kljub temu, da se starejšim delavcem (nad 50 let) pogosto pripisujejo pozitivne lastnosti, pomembne pri delu, kot na primer izkušnje, znanje, delovne navade, kakovost, lojalnost, predanost delovni organizaciji, sposobnost, da v krizi ohranijo mirno kri, dobro sodelovanje s sodelavci ipd. (Dennis in Thomas, 2007: 86). Kljub ne tako številnim negativnim lastnostim, ki se jim pripisujejo, kot na primer neprožnost, pomanjkanje agresivnosti, odpor proti novostim, fizične omejitve, večji stroški za delodajalca, pa so te očitno bolj odločujoče predvsem takrat, ko je to tudi v skladu $\mathrm{z}$ institucionalno kulturo $\mathrm{v}$ določeni delovni organizaciji.

Avtorici, ki sta preučevali stanje na trgu delovne sile in stališča delodajalcev do starejših delavcev v Avstraliji, ${ }^{8}$ sta ugotovili, da temelji najtežji del reform $v$ podjetništvu na starejših, ki običajno postanejo odvečni del podjetja. Ugotavljata, da se obdobje starosti razlikuje od mladostništva, saj je le starost tista, ki se jo v podjetju identificira kot problem; oblikuje se kategorije starejših delavcev in razpravlja o njihovi identiteti ter posledicah, ki jih razlike imajo (Ainsworth in Hardy, 2008: 390). Podjetniška kultura je povezana z mladostjo, diskurz o letih/staranju pa je povezan s pre- vladujočim kulturnim opredeljevanjem staranja kot neizogibnega upadanja (moči, vpliva ipd.). To je $\mathrm{v}$ nasprotju $\mathrm{z}$ raziskavami, ki kažejo, da se mentalne sposobnosti pri starejših (v zadnjem stoletju) izboljšujejo, strokovnjaki zlasti $\mathrm{v}$ zadnjih desetletjih ugotavljajo, da velja to tudi za stare od 50 do 79 let, kar je verjetno tudi posledica podaljševanja izobraževanja in usposabljanja na delovnem mestu (Romeu Gordo, v: Skirbekk 2008: 7). Plačano delo postaja fizično manj naporno, v mnogih evropskih državah se zmanjšuje tudi število delovnih ur, ki jih na leto opravijo delavci, kar vpliva na zahtevnost dela, predvsem $z$ vidika zdravja (Henretta, 2000). Vsi ti podatki kažejo na nesmiselnost ukoreninjenih stereotipnih predstav o zmožnostih starejših delavcev, ki posredno vplivajo tudi na njihove lastne predstave o svojem položaju na trgu dela. Ugotovimo lahko, da uspešnost na delovnem mestu pogosto res pada s starostjo, vendar ne pri vseh nalogah in še posebno ne pri poklicih, kjer so pomembne sposobnosti, ki z leti ne upadajo (Skirbekk, 2008: 7). Gotovo pa na delovno uspešnost vpliva tudi motivacija za delo, ki je povezana $\mathrm{z}$ mnogimi dejavniki, na katere starejši delavci zdaj nimajo vpliva. V prid starejšim govorijo podatki o njihovem zdravstvenem stanju (Henretta, 2000: 288-289): večina raziskav kaže, da so starejši delavci v boljšem zdravstvenem stanju in imajo boljše zmožnosti za delo, kot je to veljalo v preteklosti; to bo verjetno veljalo tudi za prihajajoče generacije starejših in bo vplivalo na drugačno družbeno pojmovanje starosti.

Razlika v izobrazbi med mlajšimi in starejšimi zaposlenimi bo v razvitih državah v prihodnosti manjša, na kar bo vplivalo več dejavnikov. Henretta (2000: 288) pravi, da bo vse bolj verjetno, da se bodo zaposleni tudi sredi svoje delovne kariere odločali za formalno izobraževanje in si tako izboljševali stopnjo izobrazbe; predpostavke, da se starejši delavci težje prilagajajo novostim in da so njihove veščine neustrezne, usposobljenost za delo slabša, znanje pa zastarelo, je 
Kljub temu v mnogih državah, na primer na Nizozemskem, v Franciji, Nemčiji, Španiji, Italiji in Veliki Britaniji od 30 do 70 odstotkov ljudi meni, da bi bilo treba starejše delavce prisiliti v upokojitev, če je služb premalo (van Ours v: Skirbekk, 2008: 8); zgodnje upokojevanje opravičujejo z dejstvom, da se tako zagotovijo delovna mesta za mlade. Van Ours meni, da bi bilo taka stališča smiselno v prihodnosti spremeniti, saj bodo razmere na trgu dela zahtevale starostno bolj raznoliko zaposlovanje; kasnejše in postopno upokojevanje naj bi bilo možno za tiste, ki si to želijo. Če bodo starejši pričakovali, da bodo delali dlje časa, se bodo pripravljeni bolj izobraževati in usposabljati. Cohen tudi meni, da bodo tako bolj posodabljali, ohranjali in razvijali svoja strokovna omrežja, kar bo lažje, če bo večji delež starejših ostajal dejaven. Tovrstna socializacija je gotovo dobra za ohranjanje mentalnega zdravja, saj je za mnoge starejše delovno mesto prostor najbolj intenzivnega srečevanja (Cohen v: Skirbekk, 2008: 8).

gotovo povezano tudi z nižjo stopnjo izobrazbe starejših delavcev v preteklosti. Pričakujemo lahko, da se bodo bolj izobražene generacije, ki prihajajo, pripravljene sproti izobraževati in bodo pri tem tudi zelo uspešne.

\section{KAJ VPLIVA NA ODLOČITVE STAREJŠIH DELAVCEV ZA NADALJNJE DELO ALI UPOKOJITEV?}

Gerontologi pogosto preučujejo pomen dela za starejše delavce. Na njihovo doživljanje vpliva veliko dejavnikov, kot na primer proces staranja, kohorta ali generacija, kateri pripada delavec, ekologija dela, spodbude in zadržki ter širši socialni kontekst obravnave tveganja, ki spremlja staranje. Lahko bi rekli, da obstajajo trije tipi starejših zaposlenih: tisti, ki morajo delati (zaradi zavarovanja ali denarja); tisti, ki želijo delati (zaradi socialnega omrežja ali uporabe znanja); in tisti, ki delajo iz obeh razlogov.

Ugotovitve raziskav kažejo, da večina delavcev v določenem obdobju zapusti karierno zaposlitev ${ }^{9}$ in se vsaj delno upokoji. Han in Moen (1999: 223-225), ki sta preučevala vpliv različnih življenjskih poti posameznikov na upokojitvene vzorce, sta ugotovila, da gre pri odločitvi za upokojitev za zelo kompleksne vplive. Na splošno je upokojitveni vzorec odvisen od treh dejavnikov: od zgodovinskega konteksta (zunanji vplivi), družbene heterogenosti (spol in social- ni vplivi) in posameznikove življenjske poti (karierna pot). Posamezno ali v kombinaciji ti vplivajo na vedenje, ki sproži proces upokojevanja. Čeprav je vpliv dejavnikov težko poenostavljati, bi lahko rekli, da ima najmočnejši vpliv na odločitev za upokojitev ravno biografska pot posameznika, na katero vpliva stopnja izobrazbe in ki se odraža $\mathrm{v}$ poklicni karieri. Seveda pa je vsaka življenjska pot posameznika vpeta $\mathrm{v}$ zgodovinski kontekst, ki ga ne smemo zanemariti; tako rezultati kažejo, da se moški, ki so $\mathrm{v}$ preteklosti tvorili glavnino delovne sile, upokojujejo prej

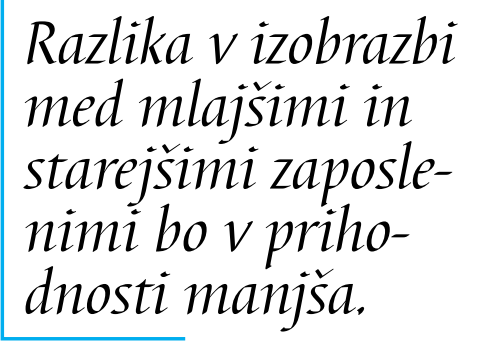
kot ženske, še posebno če so imeli tradicionalno poklicno pot. Kažejo tudi, da na zniževanje povprečne upokojitvene starosti močno vplivajo dolgoročna zgodovinska gibanja, ki najbolj vplivajo na tradicionalno delovno silo (Han in Moen, 1999: 224).

$\mathrm{Na}$ vprašanja, zakaj delajo, so starejši v raziskavi, ki jo je opravil Center za staranje in delo v Bostonu, odgovarjali: »se dobro počutim«, »sem koristen«, »delo je zame podaljšek mene samega, mora imeti pomen in smisel«, »delam, da si zagotovim zdravstveno zavarovanje «, »delam zaradi denarja, moram živeti «... (Smyer in Pitt-Catsouphes, 2007: 24). Raziskave kažejo neposredno povezanost zaposlenosti z zadovoljstvom $\mathrm{v}$ življenju posameznikov pa tudi $\mathrm{z}$ ekonomskimi razlogi starejših od 65 let. Neprostovoljna upokojitev oziroma izguba dela ima 
S staranjem se spreminja pogled na delo in kariero; čas, povezan z osebnim življenjem in delom, se zdaj ne vrednoti več z vidika, koliko ga je že preteklo, temveč z vidika, koliko ga je še ostalo. Pri tem gre za prepletanje »treh življenjskih področij : izobraževanja, dela in prostega časa (Smyer in Pitt-Catsouphes, 2007: 24). Pretežni del 20. stoletja se je večina odraslih vključevala v te dejavnosti bolj ali manj linearno - izobraževanje je potekalo na začetku življenja, delo večji del sredine življenja, prosti čas pa je postal sinonim za upokojitev. Vendar tako razmišljanje ne ustreza več spremenljivemu (fluidnemu) poteku življenja v sodobni družbi. Ljudje se izobražujejo, delajo in počivajo v različnih življenjskih obdobjih, pač glede na družinske in druge potrebe. Ta fluidnost je zabrisala tudi meje med delom in upokojevanjem starejših delavcev. Raziskava o zdravju in upokojevanju (Cahill in dr. 2006a) ugotavlja, da se večina starejših Američanov upokojuje postopno, v fazah, in pri tem izbira »premostitvena dela«, v okviru katerih delajo manj kot polni delovni čas.

negativni učinek na fizično in mentalno zdravje starejših delavcev (Gallo idr., 2000). Po drugi strani zdravje vpliva na naravnanost starejših delavcev do upokojitve - zdravi delavci redkeje razmišljajo o upokojitvi oziroma so pripravljeni delati dlje od običajnih upokojitvenih let. Seveda pa lahko po drugi strani slabo zdravje prisili starejše delavce $\mathrm{v}$ upokojitev.

Zanimivo je, da starost in zdravje na odločitve moških in žensk o zgodnejši upokojitvi vplivata različno. Leta imajo bistveno manjši vpliv na odločitve žensk, da bi se zgodaj upokojile, kot to velja za moške (Pienta idr., 2002: 204).

\section{S starostjo se pove- čuje pomen dela za obcutek samozave- stnosti.}

Ugotovili so, da zdravje ne vpliva na odločitve in pričakovanja žensk, koliko časa bodo še delale, kar je presenetljivo; so pa ženske (po njihovih navedbah) večinoma bolj zdrave kot moški, imajo manj kroničnih bolezni in težav pri delu. Življenjske delovne izkušnje žensk in moških so različne; moški pogosteje opravljajo fizično bolj zahtevna dela, ženske pa bolj kognitivno zahtevna (Pienta idr., 2002: 204). Moški so pogosteje samozaposleni, ženske pa pogosteje delajo s skrajšanim delovnim časom.

Zaposleni, ki najdejo smisel $\mathrm{v}$ delu in so $\mathrm{z}$ delom zadovoljni, so bolj pripravljeni delati dlje. Plačano delo je splošno priznano kot pomembna vloga odraslih, je indikator kompetentnosti, nadarjenosti in vsestranskosti odraslega (Smyer in Pitt-Catsouphes, 2007: 26).
Raziskava Haris Interactive (2005) je pokazala, da se je kar 59 odstotkov starejših delavcev (starih 55 let in več) strinjalo, da izhaja velik del njihove samozavesti iz njihove kariere ali dela. Odstotek starejših delavcev, ki tako menijo, je višji kot odstotek mlajših, kar kaže, da se s starostjo povečuje pomen dela in kariere za občutek koristnosti in samozavestnosti. Druga raziskava je pokazala, da večina starejših delavcev pri delu uživa; delo jim je zanimivo, navajajo, da še niso dosegli vseh poklicnih ciljev in da se čutijo sposobne, da bi prevzeli še več odgovornosti (Smyer in PittCatsouphes, 2007: 26). Kot pomembno navajajo tudi socialno omrežje, ki izhaja iz dela in zaposlitve. Moški v večji meri kot ženske dopuščajo verjetnost, da bodo delali tudi po svojem 62. letu; pogosteje tudi pričakujejo, da bodo s polnim delovnim časom delali tudi po 65. letu.

Ženskam, ki so delovno kariero prekinile zaradi vzgoje otrok, je delo manj pomembno kot tistim, ki so imele neprekinjeno delovno kariero. Podatki kažejo, da so ženske manj navezane na delo in da so tudi njihovi upokojitveni vzorci drugačni; ženske z neprekinjeno delovno kariero dlje odlagajo upokojitev kot ženske, ki so delo prekinile zaradi vzgoje otrok (Pienta idr., 2002). Manj je dokazov o vplivu delovnih pogojev na upokojitvene vzorce žensk. 
Strokovne razprave ekonomistov in sociologov v zadnjem času poudarjajo tudi premislek o upokojitvenih vzorcih kot družinski odločitvi, saj raziskave kažejo, da upokojitveni vzorci niso odvisni le od posameznikovih dosežkov na trgu delovne sile, temveč tudi od pričakovanj in možnosti partnerja. Veliko starejših delavcev še skrbi bodisi za starše bodisi za partnerja, otroke ali vnuke, tako da se mnogi ne upokojijo iz finančnih razlogov. Moški je v povprečju še vedno (bolj) pomemben pri zagotavljanju blagostanja družine, kar še posebno velja za ZDA in tudi mnoge druge zahodnoevropske države. Odločitev moškega o upokojitvi je odvisna od položaja na delovnem mestu, uspešnosti kariere, po drugi strani pa od gmotnega položaja njegove družine. Pari, ki so bolj premožni, redkeje načrtujejo delo tudi po 62. letu. Večje blagostanje torej parom ponuja večjo možnost odločanja med delom in prostim časom (Pienta idr. 2002: 205). Kljub ugotavljanju pomena in vpliva skupnih odločitev se še vedno večina raziskav osredotoča na vedenjske vzorce posameznika pri upokojevanju.

\section{IZOBRAŽEVANJE STAREJŠIH NA DELOVNEM MESTU: PRIMERA FINSKE IN JAPONSKE}

\section{Finska}

$\mathrm{V}$ zadnjem času velja Finska za model države $\mathrm{z}$ ustrezno politiko staranja. $\mathrm{V}$ zadnjih desetih letih so stopnjo delovne aktivnosti starejših (55-64 let) povečali s 36,2 odstotka v letu 1998 na 52,7 odstotka v letu 2005 (Kajzer, 2007). Finska vlada je izvedla reformo politike zaposlovanja starejših delavcev, ki je bila rezultat sodelovanja s strokovnjaki in različnimi združenji, ki so si želeli boljše delovne pogoje za starejše delavce. Reformo je sestavljalo več programov, ki so jih izvedli v okviru načrtne politike dejavnega staranja, med drugim so sprejeli nacionalni program za starejše zaposlene, nacionalni program za blaginjo na delovnem mestu, nacionalni program razvoja delovnih mest in nacionalni program za produktivnost.

Znotraj teh programov je izredno pomembno zagotavljanje možnosti vseživljenjskega učenja, ki spodbuja razvoj strokovnosti in znanja delovne sile, prispeva pa tudi k sodelovanju starejših in mlajših na delovnem mestu.

Eden od programov, ki jih je podpirala finska vlada, je program NOSTE. Program NOSTE je bil eden pomembnejših vladnih političnih programov na Finskem, ki podpira enakopravnost in izobraževanje odraslih. Pomenil je preizkus odzivnosti ponudnikov izobraževanja odraslih na Finskem na potrebe nizko izobraženih odraslih (Hulkari in Paloniemi, 2008: 59), kar jim je dobro uspelo. Izvajanje programa je pomembno vplivalo na interes in osveščenost starejših delavcev, delodajalcev in izobraževalcev $\mathrm{v}$ različnih organizacijah $\mathrm{v}$ lokalnem okolju, da se $\mathrm{z}$ novimi pristopi, sodelovanjem in razumevanjem potreb delavcev lahko izboljša udeležba najmanj izobraženih starejših delavcev v izobraževanju. Program, ki se je začel leta 2003 in končal leta 2007, je bil namenjen zaposlenim brez kvalifikacij, starim od 35 do 59 let, z namenom, da zaključijo temeljno izobraževanje. Program je bil v celoti financiran iz državnih sredstev in zato brezplačen tako za udeležence kot za delodajalce, kar je interes delodajalcev za progam zelo povečalo. Vključilo se je 16.000 udeležencev, tretjina jih je bila stara nad 50 let. Večina se je udeležila poklicnega izobraževanja, pomembno je bilo tudi področje informacijsko-komunikacijske tehnologije.

Mnoge izobraževalne institucije so razvile nove pristope, da bi se bolj približale izbrani ciljni skupini. Ponudniki so možnosti izobraževanja predstavili $\mathrm{v}$ delovni organizaciji, $\mathrm{z}$ neposrednimi diskusijami, ti neposredni stiki pa so se pri evalvaciji izkazali kot posebno pomembni za spodbujanje udeležbe starejših zaposlenih. Izobraževanje je potekalo v lokalni skupnosti pa tudi na delovnem mestu (»outreach «), kar je pri izobraževanju starejših, slabše izobraženih delavcev izredno pomembno. Ugotovili so, da starejši delavci potrebujejo 
Finski sistem izobraževanja odraslih je zelo razvejan in raznolik in mreženje med institucijami se pojavlja šele $\mathrm{v}$ zadnjem času. Tudi izobraževalna omrežja NOSTE so nastala lokalno, brez vmešavanja vlade. $Z$ delodajalci je sodelovalo veliko izobraževalnih institucij. Tako so prišli do izredno pomembnega spoznanja, da je delovno mesto oziroma delovna organizacija eno najpomembnejših področij učenja za starejše delavce (Hulkari in Paloniemi 2008: 58). Pojavi pa se vprašanje, kako kombinirati delovni proces s teoretičnim znanjem, ki ga posredujemo z izobraževanjem in tutorstvom. Izkazalo se je, da so bili med najpomembnejšimi ravno ukrepi kot na primer obiski inštruktorjev na delovnem mestu, svetovanje pri učenju na delovnem mestu, organiziranje dela na osnovi rotacije ipd. Za uspeh programa NOSTE je bila ključna (finančna) intervencija države, saj drugače ne bi mogli vzpostaviti pogojev za ustvarjanje enakih možnosti za udeležbo.

več časa in več spodbude, da se odločijo za izobraževanje. Včasih tehtajo, ali so še sposobni izobraževanja, in čeprav je izobraževanje med starejšimi cenjeno, imajo pogosto predsodke, ki največkrat temeljijo na slabih izkušnjah iz šole. Odrasli po 50. letu pogosto izobraževanja ne prištevajo med možnosti, primerne zanje. Med programom so ugotovili, da so imeli udeleženci, posebno starejši, slabe pisne in bralne spretnosti; še pomembnejša pa je bila ugotovitev, da so imeli manj izobraženi starejši bistveno večje potrebe po osebnem izobraževalnem svetovanju in pomoči kot njihovi mlajši soudeleženci. Kljub izkazanih veliki potrebi po individualnem svetovanju in finančnih sredstvih, ki so bila na voljo, pa jih izobraževalne organizacije niso dovolj izkoristile, kar so organizatorji programa ocenili kot veliko pomanjkljivost, ki jo bo treba $\mathrm{v}$ prihodnje odpraviti.

\section{Japonska}

Japonska družba se zelo hitro stara, v skladu $\mathrm{s}$ tem se zmanjšuje tudi delež populacije $\mathrm{v}$ delovnem obdobju. Zadnji podatki kažejo, da bo proces staranja na Japonskem še mnogo bolj intenziven, kot so sprva pričakovali. Po ocenah bo do leta 2010 eden od treh prebivalcev starejši od 60 let (Katsuhito, 2003: 83). Na Japonskem je rodnost nizka, življenjska doba pa se daljša. Generacija »baby-booma« se počasi upokojuje. Izredno stanje na Japonskem vpliva, da so pritiski politike na premik od razmišljanja o »starejših, ki potrebujejo pomoč« k razmišljanju o »starejših, ki lahko nudijo pomoč«, še toliko bolj intenzivni. Motivacija za delo je na Japonskem zelo visoka, stopnja zaposlenosti bistveno višja kot v državah Evropske unije. Na Japonskem sta pri starosti 60 let zaposleni dve tretjini moških, pri starosti blizu sedemdesetih pa je še vedno zaposlena polovica moških (Katsuhito, 2003: 83). Več kot 80 odstotkov starejših delavcev kot motiv za delo navaja ekonomske razloge (Ohsako in Suzuki, 2008: 92). Japonska je že uvedla postopno upokojevanje, s katerim bo poskušala motivirati zdrave starejše delavce, da bi bili zaposleni do 70. leta. To zahteva prilagojene možnosti zaposlovanja, ki bodo ustrezale drugačnim potrebam starejših delavcev.

Na Japonskem je v preteklosti veliko izobraževanja potekalo na delovnem mestu (»on-thejob-training «); sčasoma, ob slabših ekonomskih razmerah, je bilo tega izobraževanja vse manj, še posebno za starejše delavce. Več kot polovica podjetij ponuja tudi izobraževanje in usposabljanje zunaj podjetja; to pomeni, da poteka izobraževanje po vsej širini življenja (kar je glavno načelo vseživljenjskosti učenja); izobraževanje in usposabljanje potekata na delovnem mestu, v skupnosti, izobraževalnih institucijah, javnih in zasebnih agencijah za usposabljanje in doma (Ohsako in Suzuki, 2008: 90). Na Japonskem predstavljajo starejši delavci (stari nad 45 let) 16 odstotkov vseh brezposelnih oseb, in ko postanejo starejši enkrat brezposelni, je njihova ponovna zaposlitev lahko zelo problematična. Delodajalci 
tudi ne spodbujajo izobraževanja starejših delavcev. S pokojninsko reformo iz leta 1994 je Japonska dvignila starostno mejo za pridobitev državne pokojnine s 60 na 65 let, kar se bo progresivno spreminjalo do leta 2025; popravljeni zakon »Employment Security Law « določa delodajalcem, da naj se starejši delavci ne upokojujejo do starosti 62 let, do leta 2013 bodo priporočila glede starostne meje upokojevanja dvignili na 65 let. Starejši delavci na Japonskem se v veliki meri zavedajo, da je potrebno stalno izobraževanje, da bi lahko sledili potrebam, ki se pojavljajo, zato načeloma izbirajo med vključitvijo v vseživljenjsko učenje za spremembo poklica in ponovno zaposlitvijo ali pa se vključijo v drugačne poklicne oblike (delni čas, samozaposlitev, zaposleni upokojenec, delo na domu).

$\mathrm{Na}$ kratko bomo predstavili tri primere možnosti izobraževanja za starejše delavce v Tokiu. V tem mestu je zaposlenih 40 odstotkov ljudi, starih nad 60 let (58 odstotkov starih od 60 do 64, 42 odstotkov starih od 65 do 69, 19 odstotkov starih nad 70 let), tako da so starejši delavci zelo motivirani za delo (pri čemer jih gotovo vodijo različni razlogi, med njimi tudi finančni). Tokijska vlada je v letu 2004 ustanovila Tokyo Shigoto Centre (Center za iskanje zaposlitve), ki starejšim od 55 let zagotavlja svetovanje in pomoč pri zaposlovanju ter jim ponuja možnost vključitve $\mathrm{v}$ različne seminarje; zagotavlja tudi skupnostno delo, ki ga organizirajo in izvajajo zasebne organizacije. Svetovanje poteka v obliki 50-minutnih seans, izvajajo pa ga karierni svetovalci in drugi strokovnjaki. Pomembna dejavnost je priprava za zaposlitveni intervju, saj podatki kažejo, da starejši delavci ne obvladajo sodobnejših oblik samopredstavitve, saj to nekako ni v skladu z njihovo tradicionalno kulturo.

V Tokiu obstajajo tudi tehnični kolidži za starejše (sedaj jih je v Tokiu enajst); programi so brezplačni, neakademski. Izvajajo dva-, tri-, in šestmesečne programe poklicnega usposabljanja, tečaji so dnevni in večerni. Ko končajo izobraževanje, učitelji starejšim delavcem pomagajo pri iskanju zaposlitve, saj sodelujejo s tokijskim zavodom za zaposlovanje. V Tokiu delujejo tudi »srebrni centri za razvoj človeških virov « (Tokyo silver HR center) za manj izobražene starejše delavce. Takih centrov je $\mathrm{v}$ Tokiu 58, vanj pa je sedaj vključenih približno 78.000 starejših delavcev. Programi so brezplačni, trajajo od 9 do 20 dni, večinoma so namenjeni usposabljanju za različna dela, ki jih starejši prevzemajo v okviru »premostitvenih zaposlitev«. Programi so zelo raznoliki, vključujejo pa vsebine, kot so: pomoč na domu, vrtnarjenje, čiščenje, spoznavanje $\mathrm{z}$ osebnim računalnikom ipd.

\section{PRIPOROČILA ZA ZAPOSLOVANJE STAREJŠIIH DELAVCEV}

Čeprav mnoge analize in podatki različnih raziskav, pa tudi različni politični dokumenti, vsiljujejo prepričanje, da je zaposlovanje starejših delavcev za državo nujnost, za delodajalce prednost, za starejše delavce pa ugodnost, tega ni mogoče nekritično sprejemati. Čeprav mnogi odrasli uživajo pri delu, nikakor ne moremo in ne smemo sklepati, da bodo vsi starejši želeli delati dlje; raziskave namreč tudi kažejo, da mnogi starejši delajo iz potrebe, da sebi ali družini zagotovijo boljši gmotni položaj. To potrjujejo tudi podatki, da socialno bolje stoječi starejši redkeje delajo dlje, kot je potrebno (Pienta idr., 2002: 205). Starejši so velika in raznolika skupina, med katerimi bo v prihodnosti veliko izobraženih in tudi sicer dejavnih ljudi z mnogo izkušnjami in različnimi potrebami po nadaljnjem vključevanju v družbo. Zaradi tega bo starejše mogoče nagovoriti le z raznolikimi možnostmi dejavnega preživljanja poznejših let, ki bodo za mnoge vključevale tudi nadaljnje delo in zaposlovanje, bodisi prostovoljsko bodisi plačano. Mnogi starejši se bodo verjetno še vedno raje umaknili s trga dela in sodelovali v skupnostnih ali družinskih medgeneracijskih projektih. 
$S$ tem namenom je treba vzpostaviti ustrezna izhodišča za dejavno politiko staranja, ki bo temeljila na načelih vseživljenjskega učenja in izobraževanja in bo spodbudna in nediskriminatorna do vseh starostnih skupin prebivalstva.

Tako za starejše kot za delodajalce in državo je gotovo zanimiva in pomembna ideja o postopnem upokojevanju, ki sicer ni nova, vendar se sedaj pojavlja bolj intenzivno. Za vse več starejših delavcev v razvitih državah bo upokojitev verjetno proces, ne pa dogodek, in bo predvidoma vključevala eno ali več zaposlitev s krajšim delovnim časom ali z delom za določen čas, ki sovpadajo z umikom s trga delovne sile. Gre za tako imenovane premostitvene zaposlitve (»bridge job $\left.\ll^{10}\right)$ med zaposlitvijo s polnim delovnim časom (karierno zaposlitvijo) in popolnim umikom s trga delovne sile. V tem času je nadaljevanje zaposlitve bolj podobno začetkom kariere, ko gre za neke vrste eksperimentiranje in iskanje prave rešitve, kot pa enoznačni poti, ki bodisi vodi $\mathrm{k}$ upokojitvi bodisi ohranja sedanje stanje. Cahill in drugi (2006a; 2006b) ugotavljajo, da je pomen premostitvene zaposlitve (»bridge job«) oziroma premostitvenih poklicev večji, kot se zdi, saj so mnogi odrasli že pred upokojitvijo delali v netradicionalnih oblikah zaposlitve. Avtorji so v ZDA izvedli obsežno raziskavo, kjer so ugotavljali pripravljenost starejših delavcev za sprejemanje premostitvenih zaposlitev (Cahil in dr., 2006a; 2006b). Njihove ugotovitve so naslednje.

- Večina moških in žensk uporablja premostitveno zaposlitev za prehod med delom s polnim delovnim časom in polno upokojitvijo.
- Do leta 2004 je med tistimi, ki so v tem času prenehali z zaposlitvijo za polni delovni čas, kar 60 odstotkov moških in žensk imelo premostitveno zaposlitev; več kot polovica teh premostitvenih zaposlitev je bilo za krajši delovni čas.

- Mlajši delavci pogosteje kot starejši prehajajo v premostitvene zaposlitve; bolj zdravi delavci (ki svoje zdravje opredeljujejo kot odlično ali zelo dobro) so pogosteje pripravljeni prevzeti premostitveno zaposlitev.

- Večina starejših Američanov, ki so opustili karierno zaposlitev za polni delovni čas, je raje najprej prevzela premostitveno zaposlitev, kot da bi se takoj v celoti umaknila s trga delovne sile.

- Na podlagi podatkov HRS (Health and Retirement Study) so ugotovili, da je kar 95 odstotkov starejših delavcev, ki so imeli premostitvene zaposlitve, odgovorilo, da gredo zelo radi na delo; med različnimi plačnimi skupinami glede tega ni bilo razlik.

- Ugotovili so tudi, da so starejši v nižjih plačnih razredih in najvišjih plačnih razredih pogosteje pripravljeni prevzemati premostitvene poklice kot starejši v srednjih plačnih razredih.

Možnosti za postopno upokojevanje, ki jih navajajo strokovnjaki, so predvsem gibljiv delovni čas, delitev dela, krajši delovni čas, ponovna občasna zaposlitev, delo na daljavo (»telecommuting $\ll)$. Ob tem Chen in Scott (2003: 70-71) navajata, da je treba poskrbeti za nekatere vzporedne ukrepe, kot so na primer sorazmerna delitev pokojnine in dohodka iz dela,

Večina ključnih sprememb pri premostitvenem zaposlovanju se je začela dogajati po letu 1990, še posebno pa po letu 2000, ko so se začela intenzivneje kazati znamenja krize. Ta je postopno vplivala na spreminjanje upokojitvenih vzorcev in višino izdatkov za pokojnine, vse to pa je vplivalo na povečanje pritiskov za podaljševanje zaposlovanja in na pogosto ponovno vstopanje starejših ljudi na trg delovne sile po upokojitvi. V okviru raziskave o zdravju in upokojevanju (Health and Retirement Study - HRS) ${ }^{11}$ so avtorji analizirali podatke in ugotovili, da spremembe $\mathrm{v}$ upokojitvenem procesu predvsem vplivajo na to, da postajajo premostitvene zaposlitve (»bridge job«) uveljavljen način izstopa iz stalne karierne zaposlitve. 
uveljavljanje različnih olajšav, zagotavljanje zdravstvenega zavarovanja za starejše delavce ipd. Take možnosti zaposlovanja bi bile verjetno zanimive tudi za starejše delavce v Sloveniji, ki se ne želijo povsem umakniti s trga dela, vendar le ob hkratnem uvajanju mnogih sprememb na področju zaposlovanja in socialne varnosti ter ob spreminjanju kulture dela. Delodajalci se vse bolj zavedajo, da na stališča do starejših delavcev močno vplivata ustrezno izobraževanje in usposabljanje glede vpliva starosti na delo; ugotavljajo, da naj bi bilo izobraževanje za preseganje stereotipov pomembna vsebina različnega izobraževanja na delovnem mestu, namenjenega vsem generacijam delavcev. Delodajalci tudi ugotavljajo, da ima generacija »baby-booma«, ki počasi odhaja iz delovnih organizacij »skozi vhodna vrata«, ogromno znanja in izkušenj, ki se tako izgubljajo. Da bi to preprečili, že vzpostavljajo različne formalne programe, s katerimi bi zmanjšali odliv usposobljene delovne sile - na primer s ponovnim zaposlovanjem upokojenih strokovnjakov, ki se $\mathrm{v}$ podjetja vračajo kot mentorji pripravnikom in študentom, ki se bodo kasneje zaposlovali v teh podjetjih, in drugim zaposlenim $\mathrm{v}$ podjetjih. Vse bolj se zavedajo pomena izvajanja medgeneracijskega usposabljanja in izobraževanja, spodbujanja ustrezne medsebojne komunikacije in pomena krepitve timskega dela. Pomembne so tudi ugotovitve, da se na starejše delavce vse prevečkrat gleda kot na učitelje/mentorje mlajšim zaposlenim, redkeje pa se izpostavlja dejstvo, da imajo tudi sami določene učne/izobraževalne potrebe (Tikkanen in Barry, 2008: 6). Učna kultura na delovnem mestu redko upošteva in podpira vključitev starejših delavcev; ti naj bi že dosegli svoj vrh, ki pa je (predvsem v majhnih podjetjih) lahko postavljen zelo nizko. $\mathrm{K}$ manjši udeležbi v izobraževanju prispevajo tudi vrednotenja starejših delavcev o sebi kot učečih se, ki so zelo slaba.

Pred delodajalci je kar nekaj pomembnih nalog, ki naj bi jih izvajala podjetja, da bi se uspešneje soočila s starajočo se delovno silo ali postopnim uvajanjem premostitvenih poklicev, ki bi bili zanimivi tudi za starejše delavce (Buck in Dworschak, 2003: 34-35).

- Ustvariti čim bolj heterogeno starostno strukturo; izogibati se starostno omejenemu zaposlovanju in množičnemu upokojevanju.

- Ustvariti letom primerna delovna mesta, ki bodo zagotavljala tudi starejšim, da delajo do takrat, ko se odločijo za upokojitev.

- Stalno posodabljati znanja v delovnih organizacijah, to velja tudi za starejše delavce; tako bi se izognili potrebi po najemanju mlajših, bolj izobraženih in usposobljenih delavcev; starejši delavci se sedaj večinoma podpovprečno udeležujejo izobraževanja in usposabljanja, kar ni le posledica varčevanja podjetij, temveč tudi slabše pripravljenosti starejših delavcev, da bi se izobraževali.

- Spodbujati možnosti za prehajanje med zaposlitvami in delovnimi mesti (»job rotation $\ll)$.

- Spodbujati medgeneracijski prenos znanja, vzpostavljati starostno mešane skupine in tako zagotavljati kombinacijo različnih znanj in spretnosti.

- Stalno vključevati starejše delavce $\mathrm{v}$ proces inovacij.

Zagotovo bo $\mathrm{v}$ prihodnosti veliko razprav o uresničevanju koncepta dejavne starosti, v katerega sodijo tudi vprašanja podaljševanja delovnih let oziroma uvajanja novih modelov upokojevanja, ki so tesno povezani tudi s politiko medgeneracijske solidarnosti. To bo gotovo $v$ interesu države, zato je naloga vladne politike z zanimivimi alternativnimi ukrepi in možnostmi spodbujati delodajalce in zaposlene, da konstruktivno razmišljajo o podaljševanju zaposlitve. Uvajanje sprememb v zaposlovanju bo zahtevalo uvajanje nove delovne in učne kulture v delovne organizacije; zahtevalo bo novo kakovost sodelovanja in vzpostavljanja omrežij med različnimi delovnimi organizacijami, nevladnimi in prostovoljskimi organizacijami, izobraževalnimi in drugimi organizacijami v lokalni skupnosti, celoten proces pa bo 
Ob vsem tem je pomembno opozoriti na pomen medgeneracijskega sodelovanja, ki je še posebno intenziven na ravni lokalne skupnosti in je gotovo ena od možnosti za vzpostavljanje medgeneracijske solidarnosti. Medgeneracijsko sodelovanje lahko poteka prostovoljsko, s pomočjo različnih izobraževalnih in drugih skupnostnih programov, v različnih oblikah premostitvenih zaposlitev v delovni organizaciji, lahko pa tudi kot občasna ali stalna vzajemna pomoč med generacijami v skupnosti, kjer starejši in mlajši drugi drugim v zameno ponudijo svoje storitve (»borza dela za upokojence «). Takih oblik medgeneracijskega sodelovanja, ki so lahko brezplačne, plačljive ali temeljijo na izmenjavi storitev ali dobrin, bo v prihodnosti gotovo vse več tudi v Sloveniji, saj so se v mnogih evropskih državah že močno uveljavile. To bo vplivalo tudi na spreminjanje pogosto stereotipnih stališč mladih ljudi, da so stari odvisni in nemočni ljudje, ki potrebujejo predvsem pomoč.

uspešno potekal le ob intenzivnem izobraževanju vseh vključenih.

V sklepu lahko torej poudarimo, da bi z ustrezno politiko zaposlovanja, ki bi jo spremljalo dobro zasnovano izobraževanje, lahko pridobili vsi, torej država, delodajalci pa tudi starejši delavci in upokojenci. Spremembe bodo mogoče le ob stalnem (splošnem in strokovnem) izobraževanju delodajalcev, različnih skupin zaposlenih, prostovoljcev pa tudi politikov, kar naj bi postopno vplivalo na manj diskriminatorno obravnavo starejših delavcev in upokojencev, ki so se pripravljeni tako ali drugače vnovič dejavno vključiti v družbo. Poleg ekonomskega vidika, ki zdaj prvenstveno vodi razmišljanja o podaljševanju zaposlovanja starejših delavcev, je treba upoštevati tudi socialne, kulturne, osebne in zdravstvene dejavnike, ki vplivajo na posameznikovo odločitev o delu ali upokojitvi. Gotovo pa bo za uvajanje vseh omenjenih sprememb potrebno tudi intenzivno osveščanje širše javnosti.

\section{VIRI}

Buck, H., Dworschak, B. (2003). »Ageing and work in Germany - Challenges and Solutions «. V Buck, H., Dworschak, B. (ur.). Ageing and work in Europe. Strategies in company level and public policies in selected european countries. Stuttgart: Fraunhofer Institute for Industrial Ingineering, 27-46.

Cahill, K. E., Giandrea, M. D., Quinn, J. F. (2006a). »Retirement Patterns From Career Employment«. The Gerontologist. 46, 4, 514-523.

Cahill, K. E., Giandrea, M. D., Quinn, J. F (2006b). »Are Traditional Retirements a Thing of the Past?
New Evidence on Retirement Patterns and Bridge Jobs«. Business Perspectives. 8, 2, 26-37.

Chen, Y.-P., Scott, J. C. (2003). »Gradual retirement: An additional option in work and retirement «. North American Actuarial Journal. 7, 3, 62-74.

Dennis, H., Thomas, K. (2007). »Ageism in the Workplace «. Generations. Spring, 2007. 31, 1, 84-89.

Gallo, W. T, et al. (2000). »Health Effects of Involuntary Job Loss Among Older Workers: Findings from the Health and Retirement Survey«. Journal of Gerontology. 2000, 55B(3), 131-140.

Hulkari, K., Paloniemi, S. (2008). »The NOSTE programme promoting lifelong learning for loweducated older workers in Finland «. Panorama. Innovative learning measures for older workers. Luxembourgh: Cedefop, 50-63.

Han, S.-K., Moen, P. (1999). »Clocking Out: Temporal Patterning of Retirement «. American Journal of Sociology. 105, 1, 191-236.

Henretta, J. 2000. »The Future of Age Integration in Employment.« Gerontologist. 40 (3): 286-292.

Hribar Milič, S. (2008). »Izzivi za prihodnji razvoj gospodarstva«. V: Krevl, I. (ur), 8. Festival za tretje življenjsko obdobje. Zbornik. Ljubljana: Inštitut Hevreka, 21-23.

Katsuhito, I. (2003). »Rapid ageing and employment policies in Japan«. V: Buck, H., Dworschak, B. (ur.). Ageing and work in Europe. Strategies in company level and public policies in selected european countries. Stuttgart: Fraunhofer Institute for Industrial Ingineering, 83-87.

Pajnkihar, T. (2008). »Zavedanje in vloga delodajalcev $\mathrm{v}$ procesu aktivnega staranja - kako izziv spremeniti v priložnost za starejše delavce in za delodajalce«. V: Krevl, I. (ur). 8. Festival za tretje življenjsko obdobje. Zbornik. Ljubljana: Inštitut Hevreka, 28-37.

Pienta, A., Mehraban, H., Mark D. (2002). »Who Expects to Continue Working After Age 62? The Retirement Plans of Couples«. The Journals of Gerontology. Jul 2002. 57B, 4, 199-208. 
Skirbekk, V. (2008). »Age and Productivity Capacity: Descriptions, Causes and Policy Options«. Ageing horizons. 8, 4-12.

Smyer, M. A., Pitt-Catsouphes, M. (2007). »The Meanings of Work for Older Workers«. Generations. 2007, 31, 1, 23-30.

Ohsako, T., Suzuki, M. (2008). »Lifelong learning policies and practices for improving older workers' employability: recent developments and challenges in Japan«. Panorama. Innovative learning measures for older workers. Luxembourgh: Cedefop, 88-101.

Walker, A. (2001). Towards active ageing in the European union. Tokyo: The Japan Institute of Labor.

\section{INTERNETNI VIRI}

EUROSTAT, Average exit age from the labour market, by gender - years. Dostopno na: http://epp.eurostat. ec. europa.eu/tgm/table.do?tab=table $\&$ init $=1 \&$ plu gin $=1 \&$ language $=$ en $\&$ pcode $=$ tsdde 420 (Pridobljeno: 20. 4. 2009).

EUROSTAT, Projected old-age dependency ratio - $\%$. Dostopno na: http://epp.eurostat.ec.europa.eu/tgm/ table.do?tab=table \&init $=1 \&$ plugin $=1 \&$ language $=\mathrm{e}$ n\&pcode=tsdde511. Pridobljeno: 20. 4. 2009.

Harris Interactive (2005). The New Retirement Survey. How Baby Boomers Will Transform Retirement. New York: Merrill Lynch. Dostopno na: http://www.ml.com/?id=7695_7696_8149_46028_ 46503_46635

Kajzer, A. (2007). »Izzivi dolgožive družbe v Sloveniji in finska politika aktivnega staranja«. V: Čuk, J., Lončar, M., Zupanec, N. (ur.). Vseživljenjsko izobraževanje in aktivno staranje. Ljubljana: Državni svet Republike Slovenije, 27-31. Dostopno tudi na: http://www.ds-rs.si/kb/ posveti/?View $=$ entry $\&$ EntryID $=82$

Program stabilnosti 2006 (2006). Vlada R Slovenije. Dostopno na: http://www.mf.gov.si/slov/tekgib/ program_stabilnosti_2006.pdf Pridobljeno: 20. 4. 2009.

Sporočilo Komisije Svetu, Evropskemu parlamentu, Evropskemu ekonomsko-socialnemu odboru in Odboru regij. Bruselj, 12. 11. 2007. Dostopno na:

http://eur.lex.europa.eu/LexUriServ/site/sl/com/2007/ com2007_0703s101.pdf (26.11. 2007).

Statistični portret Slovenije v EU 2007. Ljubljana: Urad RS za statistiko. Dostopno na: http://www.stat.si/publikacije/pub_portret.asp. Pridobljeno: 15. 3. 2008.

Statistični portret Slovenije v EU 2008. Ljubljana: Statistični urad R Slovenije. Dostopno na: http://www. stat.si/publikacije/pub_portret.asp. Pridobljeno: 15 . 4. 2009.
SURS - Kazalniki dohodka in revščine. Slovenija, 2007 - začasni podatki. Dostopno na: http://www. stat.si/novica_prikazi.aspx?id=2032. Pridobljeno: 15. 4. 2009.

SURS - Aktivno prebivalstvo. Slovenija, februar 2009 - začasni podatki. Dostopno na: http://www.stat.si/ novica_prikazi.aspx?id=2283. Pridobljeno: 17.4 . 2009.

SURS - Anketa o izobraževanju odraslih. Slovenija, 2007. Dostopno na: http://www.stat.si/novica_prikazi.aspx?id=2286. Pridobljeno: 23. 4. 2009.

$1 V$ strokovni literaturi se starejše osebe, ki sodelujejo na trgu dela, najpogosteje opredeljuje kot starejše delavce ali pa tudi kot starejše zaposlene. Običajno gre za osebe, stare nad 50 let oziroma natančneje od 50 do 65 let, vendar pa starostne meje niso enotno definirane. Tako nekateri avtorji kot spodnjo mejo za opredelitev starejših delavcev postavljajo starost nad 45 let, drugi starost nad 55 let, zgornja meja pa običajno ni natančno določena. Čeprav ni širše sprejete definicije, ki bi opredeljevala »starejšega delavca«, bomo tu starejše delavce pojmovali kot zaposlene v starosti nad 50 let, razen če bo izrecno napisano drugače.

2 Podatki za ZDA so naslednji: od upokojitve pri starosti 74 let $v$ letu 1910 prek upokojitvene starosti 70 let $v$ letu 1950, starosti 65 let v letu 1970 do upokojitve pri starosti 60 let v letu 1985 (Burtless \& Quinn 2002 v Cahill in dr. 2006a: 515; Han in Moen 1999: 192).

3 Anketa je del mednarodne ankete o izobraževanju odraslih na podlagi Eurostatovih rezultatov, ki so jo prvič izvedli leta 2007, poleg Slovenije je bilo vanjo vključenih 18 držav (SURS, Anketa o ...).

4 Podatki o sodelovanju prebivalstva, starega od 25 do 64 let, v izobraževanju in usposabljanju, so bili zbrani $v$ evropski raziskavi o delovni sili (EU Labour Force Survey). Njihova udeležba v formalnem in neformalnem izobraževanju ter priložnostnem učenju se nanaša na obdobje štirih tednov pred izvedbo ankete.

5 Anketa je bila izvedena v okviru evropskega projekta "Ageing Workforce", financirana pa s sredstvi Evropske unije.

6 Starejši delavci so bili v raziskavi $v$ skladu $z$ definicijo evropske komisije zaposleni, stari od 55 do 64 let.

7 Pečjak opredeljuje »ageizem « kot diskriminacijo starostnih skupin, kot »neke vrste lustracijo, ker izloča starejše osebe iz družbenega življenja, npr. pri prisilnem upokojevanju, vendar ne iz moralnih, političnih ali ideoloških predsodkov, temveč zaradi koledarske starosti« (Pečjak 2007: 94-95).

8 Analiza je potekala v letih 1999 in 2000, zajela pa je različne subjekte, ki tako ali drugače sodelujejo na trgu 
delovne sile (npr. posameznike, »job network" - večinoma nevladne organizacije, ki so javno financirane in bodisi izvajajo izobraževanje/usposabljanje bodisi pomagajo delavcem pri iskanju dela - skupnostne organizacije, sindikate, delodajalce, različne zveze, strokovnjake itn.). Analizirali so diskurz, ki je potekal v javnosti in med njimi glede oblikovanja identitete različnih skupin starejših ljudi, ki so želeli zaradi brezposelnosti ponovno vstopiti na trg delovne sile ali ustanoviti majhno podjetje.

9 S karierno zaposlitvijo mislimo na stalno zaposlitev in delovne naloge, $k i$ jih je oseba opravljala večino svoje delovne kariere ali vsaj $v$ zadnjih desetih letih; ta zaposlitev je povezana s posameznikovo strokovno usposobljenostjo in izobrazbo.

10 Pojem v strokovni literaturi uporabljajo predvsem Cahill, Giandrea in Quinn (2006a; 2006b).

11 Gre za longitudinalne raziskave o zdravju, upokojevanju in staranju, ki se v ZDA izvajajo od leta 1992 in jih financira Nacionalni inštitut za vprašanja staranja (National Institute fon Ageing) pri Univerzi Michigan. Inštitut vsaki dve leti zajame več kot 22.000 Američanov, starih nad 50 let, ugotavljajo pa fizično in mentalno zdravje starejših Američanov, njihovo zavarovanje, finančni položaj, družinska podporna omrežja, položaj na trgu dela in načrtovanje upokojevanja. Izvajajo poglobljene intervjuje na reprezentationem nacionalnem vzorcu, s čimer ustvarjajo bazo multidisciplinarnih in longitudinalnih podatkov, ki olajšujejo razumevanje procesov staranja. Več na http://hrsonline.isr.umich.edu/ 